\title{
Calix[4]arene-click-cyclodextrin and supramolecular structures with watersoluble NIPAAM-copolymers bearing adamantyl units: "Rings on ring on chain"
}

\author{
Bernd Garska, Monir Tabatabai and Helmut Ritter*
}

\section{Full Research Paper}

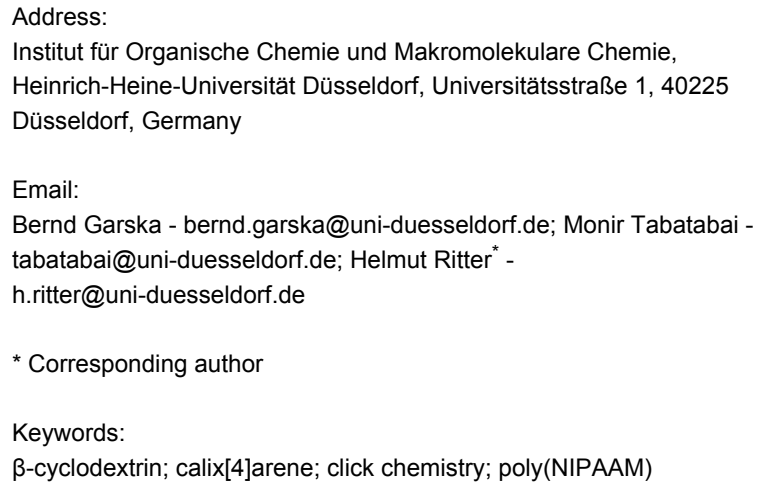

Keywords:

$\beta$-cyclodextrin; calix[4]arene; click chemistry; poly(NIPAAM)

\begin{abstract}
We describe the calixarene-cyclodextrin-coupling via click reaction starting from 5,11,17,23-tetra-tert-butyl-25,27-dipropargylether-26,28-hydroxy-calix[4]arene (calix[4]arene-dipropargylether) (2) onto 6I-azido-6I-deoxycyclomaltoheptaose (3) under microwave assisted conditions. The coupling was proven by MALDI-TOF mass spectrometry, ${ }^{1} \mathrm{H}$ NMR and IR-spectroscopy. The $\mathrm{pH}$ dependent supramolecular complex formation with poly(NIPAAM) bearing attached adamantyl units was investigated by dynamic light scattering (DLS) and turbidity measurements.
\end{abstract}

\section{Introduction}

Supramolecular interactions of macrocycles with different types of guest molecules are of increasing practical and theoretical interest [1-3]. In this context, we recently coupled cyclodextrin (CD) with cucubituril via a click reaction and investigated the special interactions with some suitable copolymers [4]. Because of their capability to form host-guest superstructures, CDs and calixarenes turned out to be very attractive not only as molecular receptors but also as building blocks for the construction of supramolecular architectures [5]. For that reason, we were encouraged to couple these two different types of macrocycles via click type reactions. Recent progress in the field of supramolecular chemistry is based on click chemistry, a versatile and powerful tool that permits the modular assembly of new molecular entities [6,7]. Both CDs as well as calixarenes have already been modified by click chemistry [8-14]. However, the coupling of calixarenes and $\beta-C D$ via click reaction and their application in the field of supramolecular chemistry has not yet been reported. Herein, we describe the synthesis and complexa- 
tion behavior of a dual type calix[4]arene-click-cyclodextrin (4) receptor by the cycloaddition of a dipropargylether of calix[4]arene (2) onto 6I-azido- $\beta$-CD (3) under microwave assisted conditions.

\section{Results and Discussion}

\section{Synthesis and characterization of compound 4}

The calixarene-click-CD compound (4) was synthesized as shown in Scheme 1.

The successful microwave assisted cycloaddition of 5,11,17,23tetra-tert-butyl-25,27-dipropargylether-26,28-hydroxycalix[4]arene (calix[4]arene-1,3-dipropargylether) (2) onto 6I-azido-6I-deoxycyclomaltoheptaose (3) was proven by IR spectroscopy by the disappearance of the bands for the azide group at $2105 \mathrm{~cm}^{-1}$ and for the propargyl group at $2115 \mathrm{~cm}^{-1}$, whilst the formation of the triazole ring was confirmed by the appearance of a new band at $1654 \mathrm{~cm}^{-1}$. The structure of compound 4 was additionally confirmed by ${ }^{1} \mathrm{H}$ NMR spectroscopy with the appearance of an olefinic proton signal at $8.07 \mathrm{ppm}$ $(-\mathrm{C}=\mathrm{CH}-\mathrm{N})$ and the disappearance of the characteristic propargyl proton signal at $2.50 \mathrm{ppm}$. Furthermore, the aromatic signals at about $7.0 \mathrm{ppm}$ and the tert-butyl groups at 1.0 to 1.2 ppm indicates the presence of the calix[4]arene component. The $\mathrm{CD}$ was confirmed by the presence of the $\mathrm{H} 2-\mathrm{H} 6$ protons at about 3.3 to $3.6 \mathrm{ppm}$, the primary hydroxy group at $4.5 \mathrm{ppm}$ and the secondary hydroxy groups at $5.7 \mathrm{ppm}$. The ${ }^{1} \mathrm{H}$ NMR spectrum of the successful cycloaddition of $\mathbf{2}$ and $\mathbf{3}$ indicates that the di-substituted calix[4]arene $\mathbf{4}$ was the major product along with a little amount of the mono-substituted compound. In addition, the MALDI-TOF-MS clearly confirmed the existence of the covalently combined rings (4) with a molecular mass of $\left[\mathrm{M}+\mathrm{Na}^{+}\right]=3066 \mathrm{~m} / \mathrm{z}(1$ calix$[4]$ arene-click- $2 \mathrm{CD})$.

DLS measurements were performed to evaluate the hydrodynamic diameter of the prepared compounds. Surprisingly, the number averaged hydrodynamic diameter of $\mathbf{4}$, which is about $150 \mathrm{~nm}$ in aqueous solution, which suggests the formation of aggregates. In comparison, the hydrodynamic diameter of $\beta-\mathrm{CD}$ in water is about $1.5 \mathrm{~nm}$, and that of calix[4]arene-1,3-dipropargylether (2) in $\mathrm{CHCl}_{3}$ is only $0.64 \mathrm{~nm}$. To reduce the agglomeration, compound $\mathbf{4}$ was deprotonated by dissolution in

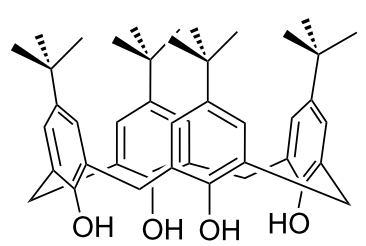

1
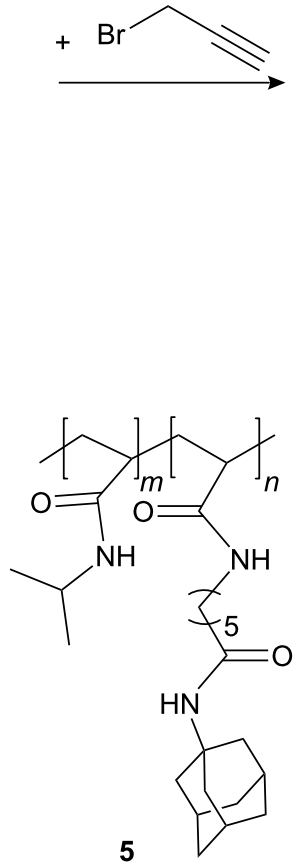

supramolecular structure
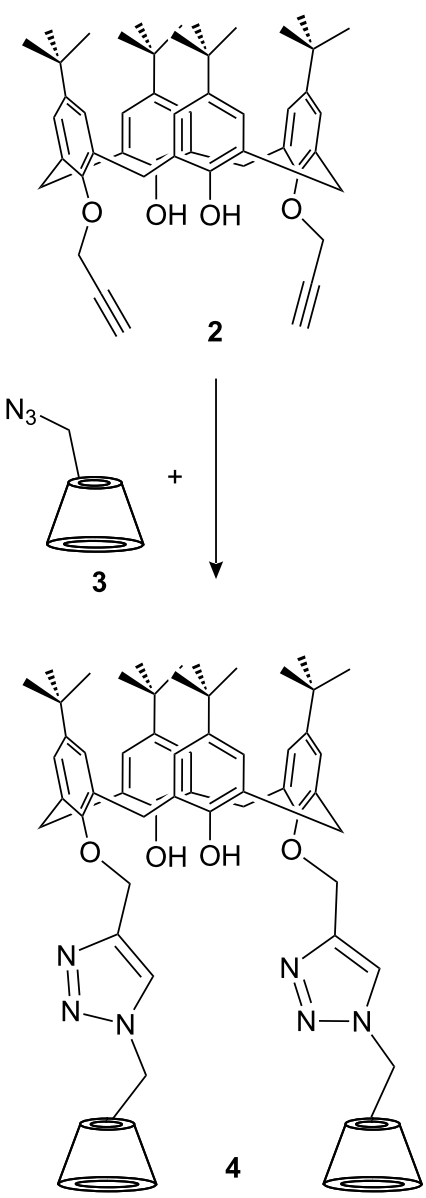
aqueous $\mathrm{NaOH}$ at $\mathrm{pH} 12$. The negative charge was expected to cause intermolecular electrostatic repulsion. Accordingly, the hydrodynamic diameter of $\mathbf{4}$ decreased in $\mathrm{NaOH}$ solution from $150 \mathrm{~nm}$ to $9.0 \mathrm{~nm}$, which can actually be attributed to the existence of trimers.

\section{Host-guest complexion of 4 and 5}

An adamantane containing copolymer 5 was prepared via free radical polymerization of 6-acrylamido- $N$-adamantyl-hexane amide and NIPAAM. Copolymer 5 was mixed with 4 subsequently (Scheme 2) to form supermolecular structures.

The hydrodynamic diameter of copolymer 5 increased from 8.5 $\mathrm{nm}$ to $53 \mathrm{~nm}$ after addition of 4 . This clearly indicates the inclusion of a polymer attached adamantane moiety into the cavity of $\mathrm{CD}$. The adamantane moiety is known to be one of the best guest molecules for $\beta$-CD [15]. A relatively high complex stability constant for a polymer attached adamantane groups with $\mathrm{CD}$ is about $5000 \mathrm{M}^{-1}$ [16]. Therefore, as shown in Scheme 2, compound 4 obviously is expected to act as an intermolecular linker between the copolymer chains. To prove the assumed agglomeration of the CD-moieties in water [17], adamantyl carboxylate was added to the solution as a competitive guest molecule. As expected, a decrease of the hydrodynamic diameter from $53 \mathrm{~nm}$ to $13 \mathrm{~nm}$ was observed. Adamantyl carboxylate is known to be a more effective guest [15] than the polymer attached adamantane moiety itself. Thus, the inclusion of the low molecular weight adamantyl carboxylate into the cavity of the $\mathrm{CD}$ component of 4 leads to a replacement of copolymer $\mathbf{5}$.

\section{$\mathrm{pH}$-Depending and LCST measurements of the host-guest complex}

To prevent the agglomeration effects of the $\mathrm{CD}$ in compound 4 as discussed above, copolymer 5 and compound 4 were dissolved in an aqueous $\mathrm{NaOH}$ solution at $\mathrm{pH} 12$ to deprotonate the free phenolic groups of the calix[4]arene-derivative 4 . After that, the hydrodynamic diameter of copolymer $\mathbf{5}$ increased due to complexation with negatively charged $\mathbf{4}$ from $8.5 \mathrm{~nm}$ to $17.5 \mathrm{~nm}$. This increase of the hydrodynamic diameter again indicates the inclusion of the polymer attached adamantane moiety into the cavity of the CD-component. Comparing the diameters of complex $(4+5)$ at $\mathrm{pH} 7(53 \mathrm{~nm})$ and at $\mathrm{pH} 12$ $(17.5 \mathrm{~nm})$, it can be supposed, that due to deprotonation inter-

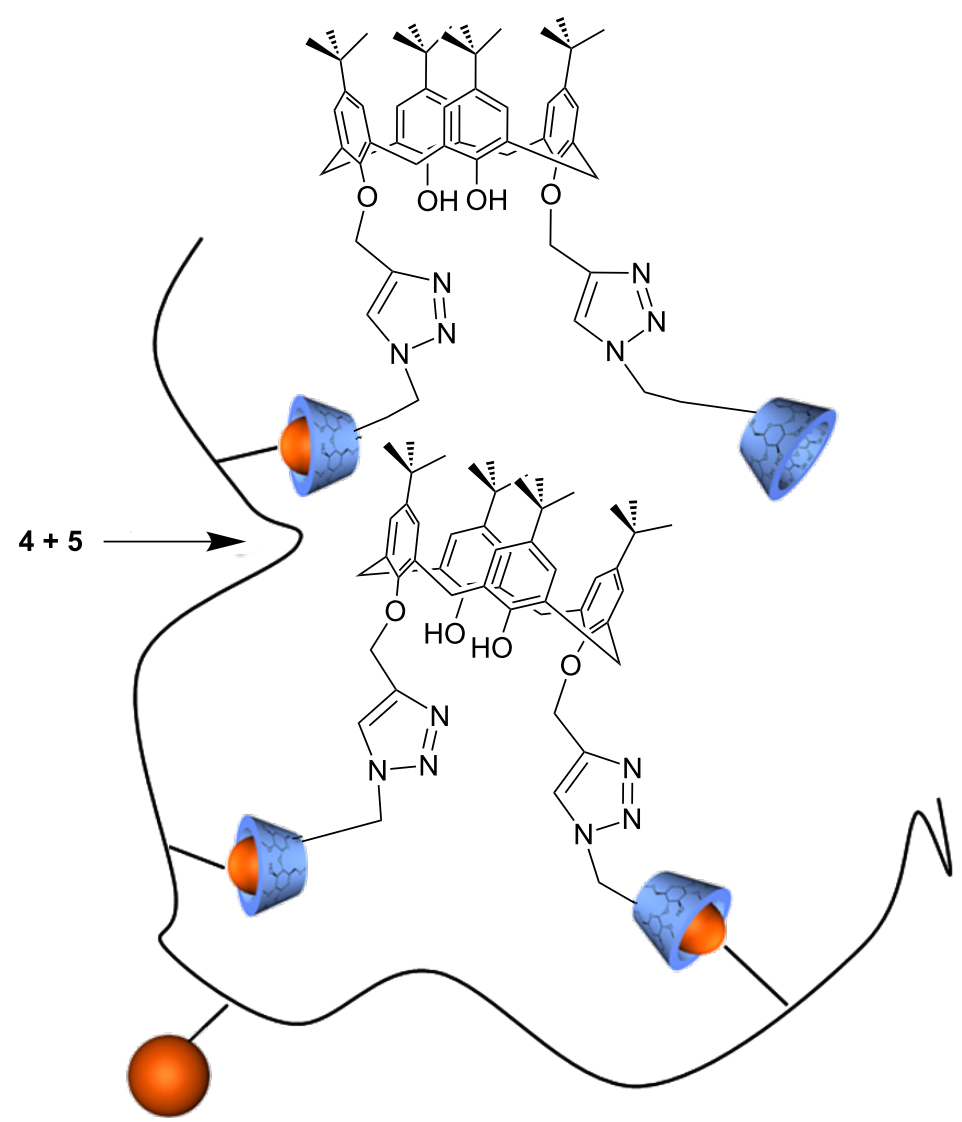

Scheme 2: Superstructure of calixarene-click-cyclodextrin $\mathbf{4}$ and copolymer $\mathbf{5 .}$ 
molecular electrostatic repulsion takes place which decreases the agglomeration in the system.

The turbidity point of copolymer $\mathbf{5}$ in water, $29^{\circ} \mathrm{C}$, is significant lower than that of the unmodified poly(NIPAAM) at $34{ }^{\circ} \mathrm{C}$, which can be ascribed to the existence of the hydrophobic adamantyl units in the copolymer. The host-guest effect of the coupled rings $\mathbf{4}$ on the cloud point of copolymer $\mathbf{5}$ was evaluated by turbidity measurements. Only a slight positive shift of the cloud point temperature from $29{ }^{\circ} \mathrm{C}$ to $30^{\circ} \mathrm{C}$ was found (Table 1). The temperature shift relative to the cloud point of poly(NIPAAM) itself, can be explained by the inclusion of the hydrophobic adamantyl units of $\mathbf{5}$ by the CD moiety of $\mathbf{4}$, which, in principal, should increase the cloud point temperature. In contrast to this, the unavoidable presence of the hydrophobic calixarene units of $\mathbf{4}$ leads to a reduction of the cloud point temperature. Repeating the turbidity experiment at $\mathrm{pH}$ of 12 , the cloud point temperature of the copolymer $\mathbf{5}$ decreased from the original $29{ }^{\circ} \mathrm{C}$ to $23{ }^{\circ} \mathrm{C}$ due to salt and $\mathrm{pH}$ effects [18] However, after adding the calixarene-click-cyclodextrin (4) to copolymer 5 under similar conditions at $\mathrm{pH} 12$, the cloud point increased to $30.5{ }^{\circ} \mathrm{C}$. This increase of the cloud point can be explained by the deprotonation of the calixarene moiety of 4 to the corresponding phenolate structure, which causes an increase in hydrophilicity.

\begin{tabular}{|c|c|c|}
\hline $\begin{array}{l}\text { Compound } \\
\text { number }(\mathrm{pH})\end{array}$ & Turbidity point $\left({ }^{\circ} \mathrm{C}\right)$ & $\begin{array}{c}\text { Number averaged } \\
\text { hydrodynamic } \\
\text { diameter }(\mathrm{nm})\end{array}$ \\
\hline $4(7)$ & & 150 \\
\hline $4(12)$ & & 9.0 \\
\hline $5(7)$ & 29.0 & 8.5 \\
\hline $5(12)$ & 23.0 & 8.5 \\
\hline $5+4(7)$ & 30.0 & 53.0 \\
\hline $5+4(12)$ & 30.5 & 17.5 \\
\hline
\end{tabular}

aDLS measurements were performed at $10^{\circ} \mathrm{C}$, below the turbidity point of the copolymer.

\section{Conclusion}

A calixarene-click-cyclodextrin combi-receptor (4) was synthesized via copper-catalyzed Huisgen 1,3-dipolar cycloaddition. Investigations of the interactions with an adamantyl moiety containing copolymer have been carried out, showing the existence of a supramolecular structure. Due to deprotonation of the calixarene moieties at higher $\mathrm{pH}$ values, a significant change in solubility and hydrodynamic diameter was observed and correlated to the formation of superstructures.

\section{Experimental}

Materials. $\beta$-Cyclodextrin ( $\beta$-CD) was purchased from Wacker Chemie GmbH (Burghausen, Germany) and used after drying overnight over $\mathrm{P}_{4} \mathrm{O}_{10}$ under an oil pump vacuum. $N$-Isopropylacrylamide (NIPAAM) 97\%, sodium azide (99.5\%) and azobisisobutyronitrile (98\%) were purchased from Aldrich Chemicals (Germany) and used as received. Copper-(II)-sulfate pentahydrate (99\%) was obtained from Carl Roth GmbH \& CO., and sodium L(+)-ascorbate (99\%) obtained from AppliChem (Germany). N,N-Dimethylformamide (DMF) and sodium hydroxide $(\mathrm{NaOH})$ were purchased from VWR (USA). Dimethylsulfoxide- $d_{6} 99.9 \%$ atom\% D was obtained from Deutero GmbH (Germany). Commercially available reagents and solvents were used without further purification. calix[4] arene 1 [19], calix[4] arene-1,3-dipropargylether 2 [8], 6I-azido-6I-deoxycyclomaltoheptaose 3 [20] and poly(6-acrylamido- $N$-adamantyl-hexane amide-co-NIPAAM) 5 [4] $\left(M_{\mathrm{w}}\right.$ : $94900 \mathrm{~g} / \mathrm{mol}$, PDI: 3.5 ) were prepared according to methods described in literature.

Measurements. IR spectra were recorded with a Nicolet 6700 FTIR (Fourier transform infrared) spectrometer equipped with an ATR unit. The measurements were performed in the rage of 4000-300 $\mathrm{cm}^{-1}$ at room temperature. ${ }^{1} \mathrm{H}$ NMR spectra were recorded on a Bruker Avance DRX 200 at $20{ }^{\circ} \mathrm{C}$. Chemical shifts were referenced to the solvent value $\delta 2.51$ for DMSO- $d_{6}$. Matrix assisted laser desorption ionization time of flight mass spectrometry (MALDI-TOF-MS) was performed on a Bruker Ultraflex TOF mass spectrometer. Ions formed with a pulsed nitrogen laser $(25 \mathrm{~Hz}, 337 \mathrm{~nm})$ were accelerated to $25 \mathrm{kV}$, the molecular masses being recorded in linear mode. 2-(4-Hydroxyphenylazo)benzoic eacid (HABA) in DMF $(25 \mathrm{mg} / \mathrm{mL})$ was used as matrix. The samples ( $1 \mathrm{mg} / \mathrm{mL}$ in DMF) were mixed with the matrix solution at volumetric ratios of $1: 10$. Gel permeation chromatography (GPC) analyses were performed on a GPC system from PPS with PPS-WIN-GPC software 4.01, 6.1 with $N, N$-dimethylformamide as eluent. The flow rate was $1 \mathrm{ml}$ $\min ^{-1}$ and the column temperature was maintained at $60{ }^{\circ} \mathrm{C}$. A $0.1 \%(\mathrm{w} / \mathrm{w})$ polymer solution $(100 \mu \mathrm{L})$ was applied to a hydroxyethyl methacrylate (HEMA) column combination that consisted of a precolumn of $40 \AA$ and main columns of 40,100 and $3000 \AA$ porosities. The weight-average molecular weight $\left(M_{\mathrm{W}}\right)$ and the polydispersity (PD) were calculated by a calibration curve generated by polystyrene standards with a molecular weight range from 370 to 1000000 Da. DLS experiments were carried out on a Malvern HPPS-ET apparatus at a temperature value of $10{ }^{\circ} \mathrm{C}$. The particle size distribution was derived from a deconvolution of the measurement number averaged autocorrelation function of the sample by the general purpose mode algorithm included in the DTS software. Each experiment was preformed five times to obtain statistical information. Cloud 
points were determined by transmission changes (at $500 \mathrm{~nm}$ ) of the solution heated at $1 \mathrm{~K} / \mathrm{min}$ in a magnetically stirred cell; cloud points were defined as the temperature at which the transmission decreases by $50 \%$. Microwave assisted synthesis was performed using a CEM Discover synthesis unit (monomode system). The temperature was measured by infrared detection with control and maintained at constant value by power modulation. Reactions were performed in closed vessels under controlled pressure.

Synthesis of calix [4]arene-click-cyclodextrin 4 . The microwave assisted click reaction of calix[4]arene-1,3-dipropargylether (2) $(100 \mathrm{mg}, 0.14 \mathrm{mmol})$ with $6 \mathrm{I}$-azido-6Ideoxycyclomaltoheptaose (3) $(324.8 \mathrm{mg}, 0.28 \mathrm{mmol})$ was carried out in DMF in the presence of $\mathrm{Cu}(\mathrm{I})$ generated by the reduction of copper sulfate $(0.014 \mathrm{mmol})$ with sodium ascorbate $(0.07 \mathrm{mmol})$. The tube was sealed, placed in the CEM monomode microwave and irradiated at $150{ }^{\circ} \mathrm{C}$ and $100 \mathrm{~W}$ for $30 \mathrm{~min}$. The solvent was removed under reduced pressure. The crude product 4 was washed with water and dried in vacuum to afford a brown solid (yield: 70\%).

MALDI-TOF: $m / z 3066\left[\mathrm{M}+\mathrm{Na}^{+}\right] .{ }^{1} \mathrm{H}$ NMR (DMSO- $d_{6}$, $\delta(\mathrm{ppm})): 1.05\left(\mathrm{~s}, 9 \mathrm{H},-\mathrm{C}-\left(\mathrm{CH}_{3}\right)_{3}\right), 1.13\left(\mathrm{~s}, 9 \mathrm{H},-\mathrm{C}-\left(\mathrm{CH}_{3}\right)_{3}\right), 1.17$ $\left(\mathrm{s}, 9 \mathrm{H},-\mathrm{C}-\left(\mathrm{CH}_{3}\right)_{3}\right), 1.19$ (s, 9H, -C- $\left.\left(\mathrm{CH}_{3}\right)_{3}\right), 3.37$ (br, $28 \mathrm{H}$, $\mathrm{H}-2,4), 3.66$ (br, 56H, H-3,5,6), 4.48 (br, 7H, O-CH-O), 4.75 (br, 7H, O-CH-O), 4.85 (br, 12H, OH-6), 5.78 (br, 2H, Ar-OH), 6.97 (s, 2H, Ar-H), 7.01 (s, 2H, Ar-H), 7.06 (s, 2H, Ar-H), 7.10 (s, 2H, Ar- H), 7.78 (s, 1H, N-CH=C), 8.07 (s, 1H, N-CH=C). IR: 3328 (-OH), 2929 (aryl, alkyl), 1654 (triazole), 1482 $(-\mathrm{C}=\mathrm{N}-), 1386\left(-\mathrm{C}\left(\mathrm{CH}_{3}\right)\right)$; further intensive signals, 1151, 1078, $1022 \mathrm{~cm}^{-1}$.

Host-guest complexion of polymer 5 and calix[4]areneclick-cyclodextrin 4. For further investigations, polymer 5 (50 $\mathrm{mg}, 5.3 \times 10^{-3} \mathrm{mmol}$ ) was dissolved in $5 \mathrm{ml}$ water or aqueous $\mathrm{NaOH}$ at $\mathrm{pH} 12$. Product $4\left(10 \mathrm{mg}, 3.2 \times 10^{-3} \mathrm{mmol}\right)$ was added and the solution was mechanical stirred for $24 \mathrm{~h}$. This solution was centrifuged to remove undissolved particles.

\section{References}

1. Abraham, W. J. Inclusion Phenom. Macrocyclic Chem. 2002, 43, 159-174. doi:10.1023/A:1021288303104

2. Ikeda, A.; Shinkai, S. J. Am. Chem. Soc. 1994, 116, 3102-3110. doi:10.1021/ja00086a045

3. Gutsche, C. D.; Alam, I. Tetrahedron 1988, 15, 4689-4694. doi:10.1016/S0040-4020(01)86171-8

4. Munteanu, M.; Choi, S. W.; Ritter, H. Macromolecules 2009, 42, 3887-3891. doi:10.1021/ma900397m

5. De Zorzi, R.; Guidolin, N.; Randaccio, L.; Purrello, R.; Geremia, S. J. Am. Chem. Soc. 2009, 131, 2487-2489. doi:10.1021/ja808850d
6. Kolb, H. C.; Finn, M. G.; Sharpless, K. B. Angew. Chem., Int. Ed. 2001, 40, 2004-2021.

doi:10.1002/1521-3773(20010601)40:11<2004::AID-ANIE2004>3.0.CO ;2-5

7. Rostovtsev, V. V.; Green, L. G.; Fokin, V. V.; Sharpless, K. B. Angew. Chem. 2002, 114, 2708-2711. doi:10.1002/1521-3757(20020715)114:14<2708::AID-ANGE2708>3.0. CO;2-0

8. Zhan, J.; Tian, D.; Li, H.; New, J. New J. Chem. 2009, 33, 725-728. doi:10.1039/b816467c

9. Bew, S. P.; Brimage, R. A.; L'Hermite, N.; Sharma, S. V. Org. Lett. 2007, 9, 3713-3716. doi:10.1021/ol071047t

10. Pérez-Balderas, F.; Ortega-Muñoz, M.; Morales-Sanfrutos, J.; Hernández-Mateo, F.; Calvo-Flores, F. G.; Calvo-Asín, J. A.; Isac-García, J.; Santoyo-González, F. Org. Lett. 2003, 5, 1951-1954. doi:10.1021/ol034534r

11. Ortega-Muñoz, M.; Morales-Sanfrutos, J.; Pérez-Balderas, F.; Hernández-Mateo, F.; Girón-González, M. D.; Sevillano-Tripero, N.; Salto-González, R.; Santoyo-González, F. Org. Biomol. Chem. 2007, 5, 2291-2301. doi:10.1039/b706331h

12. Chan, T. R.; Hilgraf, R.; Sharpless, K. B.; Fokin, V. V. Org. Lett. 2004, 6, 2853-2855. doi:10.1021/ol0493094

13. Hoogenboom, R.; Moore, B. C.; Schubert, U. S. Chem. Commun. 2006, 38, 4010-4012. doi:10.1039/b608313g

14. Munteanu, M.; Choi, S. W.; Ritter, H. Macromolecules 2008, 41 , 9619-9623. doi:10.1021/ma8018975

15. Rekharsky, M. V.; Inoue, Y. Chem. Rev. 1998, 98, 1875-1918. doi:10.1021/cr970015o

16. Amajjahe, S.; Ritter, H. Macromolecules 2008, 41, 716-718. doi:10.1021/ma702271p

17. Bonini, M.; Rossi, S.; Karlsson, G.; Almgren, M.; Lo Nostro, P.; Baglioni, P. Langmuir 2006, 22, 1478-1484. doi:10.1021/la052878f

18. Saeed, A.; Georget, D. M. R.; Mayes, A. G. React. Funct. Polym. 2010, 70, 230-237. doi:10.1016/j.reactfunctpolym.2009.12.004

19. Gutsche, C. D.; Iqbal, M. Org. Synth. 1990, 68, 234-237.

20. Ohga, K.; Takashima, Y.; Takahashi, H.; Kawaguchi, Y.; Yamaguchi, H.; Harada, A. Macromolecules 2005, 38, 5897-5904. doi: $10.1021 / \mathrm{ma} 0508606$

\section{License and Terms}

This is an Open Access article under the terms of the Creative Commons Attribution License (http://creativecommons.org/licenses/by/2.0), which permits unrestricted use, distribution, and reproduction in any medium, provided the original work is properly cited.

The license is subject to the Beilstein Journal of Organic Chemistry terms and conditions: (http://www.beilstein-journals.org/bjoc)

The definitive version of this article is the electronic one which can be found at: doi:10.3762/bjoc. 6.83 